\title{
Microchannels Affect Runoff and Sediment Yield From a Shortgrass Prairie
}

\author{
Selina A. Koler, ${ }^{1}$ G.W. Frasier, ${ }^{2}$ M.J. Trlica, ${ }^{3}$ and J.D. Reeder ${ }^{4}$ \\ Authors are former ${ }^{1}$ Graduate Research Assistant and ${ }^{3}$ Professor Emeritus, Forest, Rangeland and Watershed Stewardship Department, Colorado State \\ University, Fort Collins, CO 80523, USA; and ${ }^{2}$ Research Hydrologic Engineer (retired) and ${ }^{4}$ Soil Scientist (retired), US Department of Agriculture, \\ Agriculture Research Service, Crops Research Lab, Fort Collins, CO 80523, USA.
}

\begin{abstract}
Runoff and sediment yield from rangelands are extremely important variables that affect productivity, but are difficult to quantify. Studies have been conducted to assess erosion on rangelands, but very little has been done to determine if microchannels (rills) affect runoff and sediment yield. Rainfall simulations were used to quantify the effects of microchannels on runoff and sediment loss on a shortgrass prairie with two types of range conditions (good and fair). Natural flow paths within plots in the two range conditions were defined and then enhanced with an ellipse-shaped hoe to create microchannels. Soil from plots was removed at two rates $\left(11.2 \mathrm{t} \cdot \mathrm{ha}^{-1}\right.$ and $\left.22.4 \mathrm{t} \cdot \mathrm{ha}^{-1}\right)$ to create three soil surface configurations. Soil was removed by vacuuming to create either a single microchannel or multiple microchannels down the plot, and the third treatment was uniform soil removal over the entire plot (sheet). Results showed significantly greater total runoff from both single and multiple microchannel treatments compared with sheet soil removal. The microchannels resulted in significantly less sediment yield per unit of runoff compared with the sheet soil removal treatment. Both runoff and sediment yield were affected by range condition. Plots that were in fair range condition, dominated by buffalo grass (Buchloe dactyloides [Nutt.] Engleman), had a greater amount of total runoff (double) but less sediment yield $(75 \%)$ than plots in good range condition that were dominated by blue grama (Bouteloua gracilis [H.B.K.] Lag. ex Stued.). The dense buffalo grass sod protected the soil surface from erosion, but water flowed freely across the sod. This study has provided a greater understanding of how microchannels affect runoff and sediment yield under different rangeland conditions, and has illustrated how plant species composition and soil surface features relate to several hydrologic functions.
\end{abstract}

\section{Resumen}

La escorrentía y la producción de sedimento de los pastizales son variables muy importantes que afectan la productividad, pero son difíciles de cuantificar. Se han realizado estudios para evaluar la erosión en pastizales, pero muy pocos se han hecho para determinar si los micro canales afectan la escorrentía y la producción de sedimento. Simulaciones de precipitación fueron usadas para cuantificar los efectos de los micros canales en la escorrentía y la perdida de sedimento en una pradera de gramínea corta con dos condiciones de pastizal (bueno y mediano). Los caminos de flujo natural dentro de las parcelas con las dos condiciones de pastizal fueron definidos y luego realzados con una azada de forma elíptica para crear micro canales. El suelo de las parcelas fue removido en dos categorías $\left(11.2 \mathrm{t} \cdot \mathrm{ha}^{-1}\right.$ y $\left.22.4 \mathrm{t} \cdot \mathrm{ha}^{-1}\right)$ para crear tres configuraciones de superficie de suelo. El suelo fue removido por aspiración para crear un micro canal individual ó micro canales múltiples en la parcela, y el tercer tratamiento lo fue la remoción uniforme del suelo (lámina). Los resultados mostraron la escorrentía total significativamente mayor para ambos tratamientos de micro canales individuales y múltiples comparados con la erosión de lámina de suelo. Los micros canales resultaron significativamente menor en la producción de sedimento por unidad de escorrentía comparada con el tratamiento de remoción de la lámina del suelo. La escorrentía y la producción de sedimento fueron afectadas por la condición de categoría. Las parcelas que estuvieron en condición justa dominadas por el zacate borreguero (Buchleo dactyloides [Nutt.] Engleman), tuvieron la mayor cantidad de la escorrentía total (doble) pero una producción menor de sedimento $(75 \%)$ que las parcelas en las condiciones buenas que estuvieron dominadas por la navajita (Bouteloua gracilis [H.B.K.] Lag. ex Stued.). El denso césped de zacate borreguero protegió la superficie del suelo de la erosión, pero el agua fluyó libremente a través del césped. Este estudio ha proporcionado un mayor entendimiento de cómo los micro canales afectan la escorrentía y la producción de sedimento bajo diferentes condiciones en los pastizales, y ha mostrado como la composición de especies de plantas y las características de la superficie de suelo se relacionan a varias funciones hidrológicas.

Key Words: channels, erosion, grassland, rainfall simulation, rills, surface hydrology

\section{INTRODUCTION}

Rangelands make up nearly $40 \%$ of the terrestrial surface of the earth, with $80 \%$ in arid and semiarid regions (Branson et al.

Research was funded by the US Department of Agriculture, Agriculture Research Service and the Colorado State University Agriculture Experiment Station.

Manuscript received 16 May 2007; manuscript accepted 10 May 2008.
1981). Many of these rangeland areas are characterized by sparse vegetation and fragile soils, which makes them susceptible to erosion during high-intensity precipitation events. Soil erosion losses result in reduced land productivity that amount to billions of dollars per year (Pimentel et al. 1995). Erosional losses could increase even more if predicted changes in rainfall patterns in the semiarid West occur (Intergovernmental Panel on Climate Change 2007). 
Runoff and erosion from rangelands is a very complex process, with each site presenting unique characteristics. Thus developing a better understanding of factors affecting surface runoff will aid in our efforts to quantify rangeland hydrologic processes. Numerous studies have been conducted in the past few decades to assess runoff and soil erosion quantities and processes from rangelands. Most of these studies were concerned with quantifying total runoff and sediment amounts that come off the land (Frasier and Holland 2004). It has only been with the advent of portable rainfall simulators that studies have been conducted to better define runoff and erosion processes from rangelands (Simanton et al. 1991). These studies have led to a better understanding of the interactions of landform characteristics (i.e., surface roughness, vegetation, and slope) and surface runoff and soil erosion.

Surface runoff is the portion of total runoff that flows over the soil surface to the nearest channel (Brooks et al. 1997). This is also commonly referred to as overland flow, which is a primary force for water erosion and sediment movement on rangelands (Gutierrez-Castillo 1994). To simplify data interpretation, many of the past rangeland runoff studies had an unwritten assumption that runoff water occurs as a uniform flow (sheet flow) across the soil surface (Abrahams et al. 1986; Abrahams and Parsons 1990; Owens et al. 1991; Guy et al. 1992). In reality, native vegetation on rangelands is not a dense solid mat, but instead consists of irregularly spaced vegetation clumps and other surface features such as litter and debris dams, which can affect surface runoff characteristics. Runoff water moves as sheet flow only a short distance before it is concentrated in small channels (microchannels) around obstructions and vegetation clumps for conveyance down the hill slope (Abrahams et al. 1995; Fiedler et al. 2002). Frasier et al. (1998) noted that runoff may be directly influenced by the connectivity of microtopography, and it may be an important characteristic in rangeland hydrology. However, until recently very few studies have examined the effects of microchannels on runoff and soil erosion on rangelands, although several researchers have acknowledged the need to further examine the effects of microchannels (Fernald 1997; Flenniken et al. 2001; Linse et al. 2001; Mergen et al. 2001; Giordanengo et al. 2003).

A microchannel is defined as any channel developed on a hill slope that is part of the network of other concentrated flow paths that function together to deliver water and sediment down the hill slope (Raff et al. 2003). Dunne et al. (1991) found a strong relationship between vegetation and microtopography. This microtopography creates microchannels, which may increase runoff, decrease infiltration, and affect sediment loss. Bank-full flow in microchannels may accelerate erosion through soil particle detachment that causes the microchannel to widen. Flenniken et al. (2001) found that changes in microchannel characteristics and vegetation significantly influenced runoff volume.

Overland flow water detaches and transports soil particles downslope (soil erosion). Sediment yield is defined as the amount of soil particles (sand, silt, and clay) present in runoff water that exits a specified area. Surface feature changes can affect sediment yield. Raff et al. (2003) noted that if surface roughness was interconnected within a bare plot, this might form a microchannel or rill. The potential for erosion from this rill might be considerable. In a cold desert system, Linse et al. (2001) found that when total vegetative cover was $<30 \%, 74 \%$ of the variability in sediment yield could be explained by cover, and microchannel networks were better developed and contributed more to sediment transport from the plots.

An understanding of the variables that affect microchannel processes is very important for maintenance of rangeland productivity (Wilcox and Wood 1989). Measurements of runoff and sediment concentration in runoff are essential to quantify and understand the hydrological and edaphological processes on semiarid rangelands (Gutierrez-Castillo 1994). Rainfall simulators are an effective tool for obtaining the required information. Runoff and sediment movement at these small scales (simulator plot size) is both frequent enough and substantial enough to be considered ecologically significant (Reid et al. 1999).

\section{Objectives and Hypotheses}

The goal for this study was to determine how microchannels affect runoff and sediment yield from a semiarid shortgrass prairie. The objectives were 1) to measure and compare runoff and sediment loss during a high-intensity simulated rainstorm from two range condition classes (good and fair), with and without enhanced microchannels; 2) to determine relationships between runoff and sediment yield with differences in soil surface cover and roughness; and 3) to determine if changes occurred in microchannel shape during rainfall simulations. Two range condition classes (good and fair) were delineated for treatment. Soil surface treatments consisted of three types of surface configurations (sheet, microchannel, and multiple microchannels) at two levels of soil removal $\left(11.2 \mathrm{t} \cdot \mathrm{ha}^{-1}\right.$ and $\left.22.4 \mathrm{t} \cdot \mathrm{ha}^{-1}\right)$. We hypothesized that 1 ) runoff would be greater and sediment yield would be less on fair-condition rangeland in plots where microchannels were enhanced by soil removal than when soil was removed as a uniform layer (sheet) from the plot surface; 2) there would be a negative correlation between surface cover and roughness with runoff and sediment yield; and 3) microchannels would not increase in depth or width during a single intense rainfall simulation.

\section{METHODS}

\section{Study Site}

The research was conducted on the US Department of Agriculture (USDA) Agricultural Research Service, Central Plains Experimental Range in north central Colorado at lat $40^{\circ} 49^{\prime} \mathrm{N}$, long $104^{\circ} 46^{\prime} \mathrm{W}$, with an elevation of $1650 \mathrm{~m}$. The climate is semiarid with mean monthly temperatures between $-4^{\circ} \mathrm{C}$ and $22^{\circ} \mathrm{C}$; annual average precipitation is $322 \mathrm{~mm}$, with $70 \%$ occurring during the growing season (April to September; Long Term Ecological Research 2001). The primary vegetation is blue grama (Bouteloua gracilis [H.B.K.] Lag. ex Stued.), and buffalo grass (Buchloe dactyloides [Nutt.] Engleman), with some western wheatgrass (Pascopyrium smithii [Rydb.] A. Love) present. The soil at the site is a coarse-loamy, mixed, mesic Ustollic Haplargid, and is classified as a Vona sandy loam. It was formed from calcareous sandy alluvial and eolian material (USDA 1982). The site had been moderately grazed by 
cattle for $50 \mathrm{yr}$, but grazing was excluded by fencing in the fall of 1997 before treatments began (VanAmburg et al. 1999).

\section{Treatments}

Plots used in our study had been used in previous studies (Thorne et al. 2005). All new treatments were randomized on old runoff treatment plots that had been stratified to ensure that previous treatments did not confound current treatment effects. Thirty-six plots, each $0.6 \times 2.0 \mathrm{~m}$, were framed with metal on all four sides. The metal sheets were $15 \mathrm{~cm}$ wide and were placed $10 \mathrm{~cm}$ into the soil. The mean plot slope was $6.2 \% \pm 0.34 \mathrm{SE}$.

In August of 2001, these plots were classified as being in either good or fair condition and 36 were randomly selected (18 good, 18 fair) for use in this study. Surface soil was removed by vacuuming to simulate conditions following soil loss by single or multiple microchannel erosion, or sheet erosion, at rates of $11.2 \mathrm{t} \cdot \mathrm{ha}^{-1}$ or $22.4 \mathrm{t} \cdot \mathrm{ha}^{-1}$. A collection bag captured the soil, which was weighed to determine when the correct amount of soil had been removed. The two levels of soil removal represent the maximum allowable soil-loss tolerance value ( $\mathrm{T}$ value; $11.2 \mathrm{t} \cdot \mathrm{ha}^{-1}$ ) and twice the maximum allowable $\mathrm{T}$ value $\left(22.4 \mathrm{t} \cdot \mathrm{ha}^{-1}\right.$; Thorne et al. 2005). The $\mathrm{T}$ value of $11.2 \mathrm{t} \cdot \mathrm{ha}^{-1}$ has been defined as "the maximum level of soil erosion that will permit a high level of crop productivity to be sustained economically and indefinitely" (Wischmeier and Smith 1978). The T value was originally developed for cultivated areas and in the absence of any other criteria has also been used as the maximum allowable erosion on rangelands (K. Renard, personal communication, 1990). Existing single and multiple flow paths within some plots were enhanced with an ellipse-shaped hoe to create microchannels, and loose soil was removed from the channels by vacuuming to remove $11.2 \mathrm{t} \cdot \mathrm{ha}^{-1}$ or $22.4 \mathrm{t} \cdot \mathrm{ha}^{-1}$. The channels were formed to mimic the shape of natural flow paths (J. Smith, personal communication, 2001). The single microchannel treatment involved soil removal at the two levels from the main channel, whereas the multiple microchannel treatment involved soil removal from a main channel and also from one to three side channels that branched off of the main channel. Sheet soil removal was accomplished by vacuuming soil as a fairly uniform layer from the entire area of the plot. Runoff and sediment data were collected from the plots in the summer of 2002 (Koler 2004).

\section{Cover and Roughness}

Canopy and ground cover were sampled using the point method (Bonham 1989) on all plots before rainfall simulations. A level pin-table containing 100 pins on a $10 \times 10 \mathrm{~cm}$ grid was used to collect data on point hits (Linse et al. 2001). Canopy and ground cover were recorded as the pins were lowered to the soil surface and intercepted a plant species, litter, rock, bare ground, or cryptogram crust. A digital micrometer incorporated onto the pin-table was used to measure microtopographic elevations in millimeters at each $10 \times 10 \mathrm{~cm}$ node point on the grid to determine surface roughness.

\section{Microchannel Characteristics}

Sinuosity and length of microchannels were determined on plots before rainfall simulations by measuring the length of a string placed down the center of each microchannel. The total length was the sum of all small increments, including branch channels. Sinuosity was calculated as the total length of the channels divided by the length of the plots. Channel lengths were not measured following the rainfall simulation because it was visually observed that channels did not change in length during the rainfall simulation (Koler 2004).

Microchannel cross-section measurements were taken on the plots before and after the rainfall simulations in three different locations marked by nails within the microchannels of each treated plot, and in naturally occurring flow paths within the sheet soil-removal plots. Measurement sites were randomly located on the bottom one-third of the plots where it was assumed that bank-full flow would occur during the intense rainfall simulations. Bank-full flow was defined to be the highest flow that could occur without overtopping the channel banks. Microchannel measurements were made using a Hempe ${ }^{\circledR}$ contour gauge. The gauge has a series of moveable metal pins that conform to the shape of the surface microtopography. The contour gauge was carefully placed into the channels so that the pins made contact with the surface without displacing any surface features such as soil, rocks, or litter. The contour of the gauge was then traced onto a sheet of paper. The procedure was repeated two times in each location and the data were averaged.

\section{Rainfall Simulation, Runoff, and Sediment Concentration}

A rotating-boom rainfall simulator, developed at the University of Wyoming (Linse 1992), was used to apply water at a rate of $150 \mathrm{~mm} \cdot \mathrm{h}^{-1}$ for $30 \mathrm{~min}$. Water was applied from three nozzles at a height of $3 \mathrm{~m}$. To minimize variability between rainfall simulator runs, the water pressure was controlled and a windscreen was used. No natural rainfall occurred during the 2-wk period of rainfall simulations; therefore it was assumed that the dry soil moisture conditions did not change during the study. Six volumetric rain gauges were placed around the perimeter of each plot to measure the amount of water applied to each plot during the 30 -min rainfall simulation. Troughs connected to the bottom of the plot frames collected water and funneled it to a collection point. Runoff was collected for $6 \mathrm{~s}$ at 2-min intervals throughout the rainfall simulation and the volume was recorded. Every other sample was stored for sediment concentration analysis.

Sediment concentration was determined using a gravity sediment filtration recovery procedure. Ahlstrom filter papers (15-cm diameter, Grade 94) were dried at $40^{\circ} \mathrm{C}$ for $4 \mathrm{~h}$, and were then individually weighed before being placed onto the mouth of $355-\mathrm{mL}$ jars. The collected runoff samples were poured into the filters. Residual sediment was washed from the sides and bottom of collection bottles with distilled water, thus ensuring that all sediment was transferred with water into the filter. The filter papers with sediment were then removed from the jars and placed in soil tins, dried at $40^{\circ} \mathrm{C}$, and reweighed. Sediment contents were calculated by subtracting the presediment from the postsediment dry filter-paper weight.

\section{Experimental Design}

The experimental design was a randomized block, with a factorial arrangement of three fixed treatments. Factor levels 


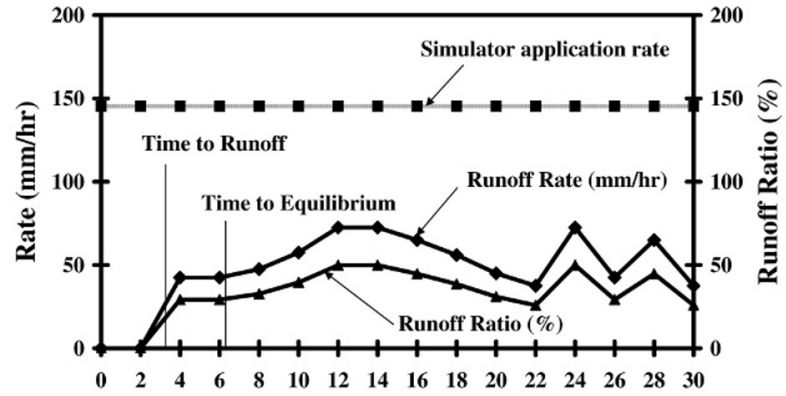

Elapsed Time (min)

Figure 1. A typical runoff hydrograph for rainfall simulation plots on shortgrass prairie, 2002.

consisted of two different range conditions (good and fair), with three types of surface configurations (sheet, microchannel, and multiple microchannels), and two levels of soil removal (11.2 $\mathrm{t} \cdot \mathrm{ha}^{-1}$ and $22.4 \mathrm{t} \cdot \mathrm{ha}^{-1}$ ). The random effect was three replications of each treatment level for a total of 36 plots. Range condition was established based on a qualitative analysis of species cover by Harvey Spock, Natural Resources Conservation Service Certified Range Specialist (Natural Resources Conservation Service 1997). The major visual and statistical differences were that plots dominated by blue grama and western wheatgrass were placed into the "good" treatment, whereas plots dominated by buffalo grass were considered to be in "fair" condition. No differences in slope or soil texture were evident between the two condition classes.

\section{Data Analysis}

Runoff and Sediment. A runoff hydrograph was constructed after the rainfall simulation on each plot using the runoff rates for each time interval, where the integrated area under the curve represented total runoff (Fig. 1). The mean rainfall rate $\left(\mathrm{mm} \cdot \mathrm{h}^{-1}\right)$ was calculated as the total rainfall $(\mathrm{mm})$ collected in the six gauges placed around the perimeter of the plots divided by the time of the simulated run $(0.5 \mathrm{~h})$. The runoff ratio was also determined for each 2-min interval of runoff. The runoff ratio is the point runoff rate $\left(\mathrm{mm} \cdot \mathrm{h}^{-1}\right)$ divided by the mean rainfall rate. The ratio was multiplied by 100 to obtain the runoff rate as a percentage of the applied water. This approach to runoff hydrograph analysis made it possible to compare the various rainfall simulator results (Frasier et al. 1998).

The runoff parameters analyzed in this study were time to runoff and total runoff. Time to runoff was defined as the time when the runoff rate exceeded $5 \%$ of the rainfall rate (Giordanengo et al. 2003).

A sedigraph was constructed from the sediment concentrations in the collected runoff water samples. Total sediment yield for each simulation was estimated as the area under the sedigraph curve divided by the area of the plot. Sediment yield is reported in $\mathrm{kg} \cdot \mathrm{ha}^{-1}$. Also calculated was the sediment yield per unit runoff $\left(\mathrm{kg} \cdot \mathrm{ha}^{-1} \cdot \mathrm{mm}\right.$ runoff $\left.{ }^{-1}\right)$. This adjusts for the amount of runoff carrying the sediment from the plot (Giordanengo et al. 2003).
Cover, Roughness, and Microchannels. Pin-table hits were categorized as grasses (by species), forbs (by species), shrubs (by species), litter, rocks, bare ground, or cryptograms. Only data for grass species, bare ground, and litter are reported because there was a very low frequency of forbs, shrubs, rocks, and cryptograms. For bare ground and litter, coverage was recorded as the percentage of hits for a given class per the total number of possible hits (100). For grasses, pin-table hits were recorded as the percentage of total hits for that species per total hits for that class on a plot; it was possible for a pin to hit a grass more than once, making the total number of possible hits greater than 100.

Surface roughness was determined for each plot as the mean standard deviation of the elevation of the 100 pins from a plane surface on the average plot slope. The elevation of the pins from the surface was determined from the digital micrometer on the pintable. Plotting the mean elevation for each row of pins and fitting a straight line to it then determined the average plot slope. The deviation of the elevation of the pins from the average plot slope was calculated, and the mean standard deviation of all 100 pins was considered to be the surface roughness for the plot.

Data from the Hempe ${ }^{\circledR}$ contour gauge was compared for prerainfall and postrainfall simulations to determine the change in microchannel shape. Change was determined by scanning the traced cross-sections into Adobe Photoshop ${ }^{\circledR}$ and allowing the program to calculate the difference in area from presimulation and postsimulation measurements. The widths of the channel cross-sections were also measured in Adobe Photoshop ${ }^{\circledR}$ to allow for comparisons within and between plots.

Data Analyses. All data were analyzed using the PROC mixed analysis of variance (ANOVA) and multiple linear regressions with forward stepwise selection (SAS Institute 1988). Fisher's Least Significant Difference procedures were used when significant differences among treatments were detected at $P<0.10$. Sediment yield statistics were analyzed in a $\log$ base 10 scale because residual plots showed increasing variance with increasing predicted means. All runoff data were transformed to a $\log$ base 10 scale to remain consistent with the sediment yield analysis. All means reported have been transformed back to actual means.

Multiple linear regression, with forward stepwise selection, was used to determine relationships between independent variables (blue grama cover, western wheatgrass cover, buffalo grass cover, bare ground cover, litter cover, standing litter, surface roughness, and slope) and runoff parameters. A separate multiple-regression analysis was used to determine the relationship between surface cover and roughness with sediment yield per unit of runoff.

\section{RESULTS AND DISCUSSION}

\section{Cover and Roughness}

Relative cover of dominant grasses was significantly different among range condition classes, as expected. The fair range condition plots had significantly less blue grama $(P=0.08)$ and western wheatgrass $(P=0.01)$ and more buffalo grass $(P=$ $0.01)$ than the good condition plots (Table 1). There were no differences among the various soil surface configurations for 
Table 1. Vegetative cover for rainfall simulation plots on shortgrass prairie, 2002.

\begin{tabular}{|c|c|c|c|c|c|c|}
\hline \multirow[b]{2}{*}{ Variables $(n=36)$} & & \multicolumn{5}{|c|}{ Pin-table hits ${ }^{1,2}$} \\
\hline & & $B G$ & Bogr & Buda & Pasm & Litter \\
\hline & & ----- & ----- & $-(\%)--$ & -------- & ------ \\
\hline \multirow[t]{2}{*}{ Range condition } & Good & $27 a^{3}$ & $48 a^{3}$ & $12 b^{3}$ & $22 a^{3}$ & $74 a^{3}$ \\
\hline & Fair & $27 a$ & $35 b$ & $56 a$ & $2 b$ & $69 a$ \\
\hline \multirow[t]{3}{*}{ Soil surface configuration } & Single microchannel & $29 a^{3}$ & $40 a^{3}$ & $30 a^{3}$ & $12 a^{3}$ & $69 a^{3}$ \\
\hline & Multiple microchannels & $29 a$ & $47 a$ & $29 a$ & $13 a$ & $74 a$ \\
\hline & Sheet & $23 a$ & $38 a$ & $43 a$ & $10 a$ & $71 a$ \\
\hline \multirow[t]{2}{*}{ Soil removal level } & $11.2 \mathrm{t} \cdot \mathrm{ha}^{-1}$ & $31 a^{3}$ & $36 a^{3}$ & $39 b^{3}$ & $12 a^{3}$ & $76 a^{3}$ \\
\hline & $22.4 \mathrm{t} \cdot \mathrm{ha}^{-1}$ & $23 b$ & $47 b$ & $28 \mathrm{a}$ & $12 \mathrm{a}$ & $69 b$ \\
\hline
\end{tabular}

${ }^{1} \mathrm{BG}$ indicates bare ground; Bogr, blue grama; Buda, buffalo grass; Pasm, western wheatgrass; and Litter, standing litter.

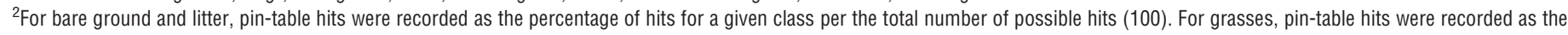

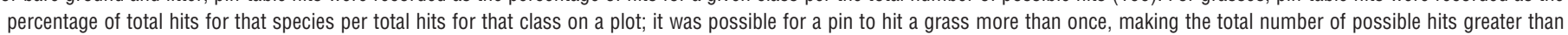
100.

${ }^{3}$ Means with the same letter, within a class of variables in a column, are not significantly different $(P>0.10)$.

cover of blue grama $(P=0.57)$, buffalo grass $(P=0.23)$, and western wheatgrass $(P=0.79)$.

There was no significant effect of range condition or the type of surface configuration on litter cover or bare ground. Litter cover was significantly affected by the soil removal level $(P=$ $0.03)$. There was $7 \%$ greater coverage of litter at the 11.2 $\mathrm{t} \cdot \mathrm{ha}^{-1}$ soil removal level as compared to the $22.4 \mathrm{t} \cdot \mathrm{ha}^{-1}$ level. These results indicated that more litter was removed during the soil vacuuming treatment process with the greater soil removal treatment level, as expected. Bare ground was also significantly affected by the soil removal level $(P=0.06)$. The $11.2 \mathrm{t} \cdot \mathrm{ha}^{-1}$ soil removal level had $8 \%$ more bare ground compared to the $22.4 \mathrm{t} \cdot \mathrm{ha}^{-1}$ soil removal level. It is not understood why this occurred as the opposite effect was expected.

Surface roughness was significantly different between range condition classes $(P<0.01)$. The mean standard deviation for surface roughness was $15 \mathrm{~mm}$ on good range condition plots, compared to a mean standard deviation of only $12 \mathrm{~mm}$ on fair range condition plots. This difference probably resulted from dominant stands of buffalo grass in the fair range condition class that created a more uniform surface microtopography.

\section{Runoff}

ANOVA showed that there were no significant interactions among range condition, type of soil surface configuration, and amount of soil removal for runoff variables measured; therefore only main effects were considered. Range condition affected time to runoff initiation $(P=0.03)$; plots in fair range condition had runoff in half the time $(2 \mathrm{~min})$ as did plots in good condition (Table 2). It was also observed, but not quantified, that spatial location of vegetation within a plot affected the time to runoff. This effect has been reported from other rangeland field studies of overland flow process (Blackburn et al. 1992; Abrahams et al. 1995). Fiedler et al. (2002) stated "... the relative importance of interactions is a function of the spatial structure of the variability and the hydrodynamics of the overland flow." Vegetation that created a barrier to flow near the bottom of a plot appeared to be less effective at delaying the time to runoff than did vegetation barriers higher on the plot. The flow at the bottom of the plot was deeper and more easily overtopped the vegetation rather than forming small ponds and infiltrating into the soil. No significant differences $(P=0.42)$ among the microchannel and sheet soil removal treatments or the level of soil removal were found for time to runoff (Table 2). Using multiple linear regressions, Giordanengo et al. (2003) found that grass cover explained little of the variability in runoff quantity, but was a significant covariate for time to runoff initiation. The present study showed that time to runoff was positively correlated with western wheatgrass cover $\left(R^{2}=0.13, P=0.04\right)$. The more western wheatgrass in a plot, the longer it took for runoff to

Table 2. Mean values (SE) of runoff parameters for rainfall simulation plots on shortgrass prairie, 2002.

\begin{tabular}{|c|c|c|c|}
\hline Variables $(n=36)$ & & $\begin{array}{l}\text { Time to runoff } \\
\text { (min) }\end{array}$ & $\begin{array}{l}\text { Total runoff } \\
(\mathrm{mm})\end{array}$ \\
\hline \multirow[t]{2}{*}{ Range condition } & Good & $4 a^{1}(0.2)$ & $30 a^{1}(1.2)$ \\
\hline & Fair & $2 b(0.1)$ & $60 \mathrm{~b}(1.3)$ \\
\hline \multirow[t]{3}{*}{ Soil surface configuration } & Single microchannel & $3 a^{1}(0.1)$ & $54 a^{1}(2.5)$ \\
\hline & Multiple microchannels & 3a $(0.2)$ & $50 \mathrm{a}(2.1)$ \\
\hline & Sheet & $3 a(0.3)$ & $34 b(1.7)$ \\
\hline \multirow[t]{2}{*}{ Soil removal level } & $11.2 \mathrm{t} \cdot \mathrm{ha}^{-1}$ & $4 a^{1}(0.2)$ & $51 a^{1}(1.4)$ \\
\hline & $22.4 \mathrm{t} \cdot \mathrm{ha}^{-1}$ & 3a $(0.1)$ & $41 \mathrm{a}(1.5)$ \\
\hline
\end{tabular}

${ }^{1}$ Means with the same letter, within a class of variables in a column, are not significantly different $(P>0.10)$. 
Table 3. Mean sediment yield values (SE) for rainfall simulation plots on shortgrass prairie, 2002.

\begin{tabular}{|c|c|c|c|}
\hline Variables $(n=36)$ & & $\begin{array}{l}\text { Sediment yield per unit runoff } \\
\left(\mathrm{kg} \cdot \mathrm{ha}^{-1} \cdot \mathrm{mm} \text { runoff }^{-1}\right)\end{array}$ & $\begin{array}{l}\text { Total sediment yield } \\
\left(\mathrm{kg} \cdot \mathrm{ha}^{-1}\right)\end{array}$ \\
\hline \multirow[t]{2}{*}{ Range condition } & Good & $135 a^{1}(5.8)$ & $4050 a^{1}(344.6)$ \\
\hline & Fair & $52 b(2.9)$ & $3120 \mathrm{a}(32.8)$ \\
\hline \multirow[t]{3}{*}{ Soil surface configuration } & Single microchannel & $59 b^{1}(2.9)$ & $3186 a^{1}(466.1)$ \\
\hline & Multiple microchannels & $79 b(8.1)$ & $3950 a(36.6)$ \\
\hline & Sheet & $145 \mathrm{a}(9.8)$ & 4 930a (397.5) \\
\hline \multirow[t]{2}{*}{ Soil removal level } & $11.2 \mathrm{t} \cdot \mathrm{ha}^{-1}$ & $104 a^{1}(5.3)$ & $5304 a^{1}(211.2)$ \\
\hline & $22.4 \mathrm{t} \cdot \mathrm{ha}^{-1}$ & $86 a(5.5)$ & $3526 a(299.5)$ \\
\hline
\end{tabular}

${ }^{1}$ Means with the same letter, within a class of variables in a column, are not significantly different $(P>0.10)$.

begin. Time to runoff was not found to be correlated with any of the other independent variables.

Total runoff was significantly greater for fair range condition plots $(60 \mathrm{~mm})$ compared with good range condition plots (30 mm; Table 2). It is suspected that this resulted from the type of vegetation present in each of the two range condition classes. Buffalo grass on fair condition plots formed a dense mat that covered almost the entire soil surface. This dense mat reduced infiltration into the soil and therefore more water was shed from the plot. These results have been documented in previous studies (Thomas and Young 1954; Mazarak and Conrad 1959). Dee et al. (1966) found on the high plains of Texas that soil under blue grama absorbed $21 \mathrm{~cm}$ of water in a 2-h period compared with only $5 \mathrm{~cm}$ beneath buffalo grass. Blackburn et al. $(1980,1986)$ also noted that infiltration was greater under bunchgrasses than sod grasses, with all other conditions being equal.

There were significant soil removal treatment effects for total runoff $(P=0.04)$. Runoff from the sheet soil removal treatment $(34 \mathrm{~mm})$ was significantly less than runoff from both the single microchannel $(54 \mathrm{~mm})$ and the multiple microchannel treatments $(50 \mathrm{~mm}$; Table 2$)$. Without a concentrated flow path, the water on the sheet soil removal plots had numerous vegetative and topographic barriers, which slowed the velocity of the runoff and allowed greater infiltration into the soil. The level of soil removal had no significant effect on the quantity of total runoff (Table 2). Multiple linear regression showed total runoff to be negatively correlated with surface roughness $\left(P=0.03 ; R^{2}=0.09\right)$, and positively correlated with buffalo grass cover $\left(P=0.19 ; R^{2}=\right.$ $0.18)$ and bare ground cover $\left(P=0.01 ; R^{2}=0.24\right)$ for a multivariate model $R^{2}$ of 0.50 . This is not unlike similar studies where other researchers have found a negative correlation between surface cover and runoff (Meeuwig 1969; Tromble et al. 1974). It is suspected that total runoff increased with the presence of buffalo grass because of dense vegetation cover over the soil sheds water, and less soil surface roughness reduced infiltration, so greater runoff occurred.

Although surface roughness was found to be a significant variable in two of the runoff parameter models, the $10 \times 10 \mathrm{~cm}$ grid measurement of random roughness of the soil surface did not detect the presence of microchannels. An ANOVA showed that little variability in surface roughness was explained by soil surface configurations $(P=0.25)$ or soil removal levels $(P=$ $0.13)$. However, surface roughness did vary significantly between the two range conditions $(P=0.01)$, with good condition range having greater random surface roughness.

\section{Sediment}

There were no significant effects among any of the treatments on total sediment yield (Table 3). However, there were significant differences among all treatments for sediment yield per unit of runoff. Sediment yield per unit runoff was significantly different $(P<0.0001)$ between the two range condition classes, where sediment yield per unit of runoff from good range condition plots was more than twice that from fair condition plots (Table 3). These results are believed to result from differences in species composition and growth form that were present in each range condition class. As previously mentioned, plots in the good range class were dominated by blue grama and western wheatgrass, whereas the plots in the fair range class consisted mainly of buffalo grass. The inherent characteristics of dense tillers within a network of stolons for buffalo grass make it better for holding the soil in place. The aboveground portion of the plant forms a mat, resulting in less soil being susceptible to raindrop splash displacement and microchannel formation. Although blue grama and western wheatgrass are also good soil binders, they do not have the mat growth form of buffalo grass to protect the soil surface, and there were more visible microchannels present. Litter cover, western wheatgrass cover, and surface roughness were all positively correlated with greater sediment yield per unit runoff (partial $R^{2}=0.21,0.18$, and 0.07 , respectively) for a model $R^{2}$ of 0.45 in the present study. Thurow et al. (1986) found opposing results where bunchgrass cover was the second most important variable of a sediment production model. They found that a sod-grass growth form did not provide a large obstruction barrier and thus had a poor, negative relationship with sediment production.

There was no significant effect of the two levels of soil removal on the sediment yield per unit of runoff (Table 3 ). However, sediment yield per unit runoff from the sheet soil surface configuration treatment was significantly greater than sediment yield per unit runoff from both the single microchannel and multiple microchannel treatments $(P=0.01$; Table 3). The total sediment removed from the plots in the three treatments were not significantly different (3 000-5000 $\mathrm{kg} \cdot \mathrm{ha}^{-1}$ ), but the total runoff from the sheet soil removal treatment was approximately $50 \%$ of the total runoff from the microchannel treatments (Table 2). This reduced volume of 
Table 4. Mean microchannel change (SE) for rainfall simulation plots on shortgrass prairie, 2002.

\begin{tabular}{|c|c|c|c|}
\hline \multicolumn{2}{|l|}{ Variables $(n=24)$} & \multicolumn{2}{|c|}{$\begin{array}{l}\text { Microchannel change } \\
\left(\mathrm{cm}^{2}\right)\end{array}$} \\
\hline \multirow[t]{2}{*}{ Range condition } & Good & $-1.1 a^{1}$ & $(0.1)$ \\
\hline & Fair & $-0.6 b$ & $(0.2)$ \\
\hline \multirow[t]{2}{*}{ Soil surface configuration } & Single microchannel & $-1.4 a^{1}$ & $(0.2)$ \\
\hline & Multiple microchannels & $-0.3 b$ & $(0.1)$ \\
\hline \multirow[t]{2}{*}{ Soil removal level } & $11.2 \mathrm{t} \cdot \mathrm{ha}^{-1}$ & $-0.9 a^{1}$ & $(0.1)$ \\
\hline & $22.4 \mathrm{t} \cdot \mathrm{ha}^{-1}$ & $-0.9 a$ & $(0.2)$ \\
\hline
\end{tabular}

${ }^{1}$ Means with the same letter, within a class of variables in a column, are not significantly different $(P>0.10)$. Negative values signify an increase in channel size following rainfall simulations.

runoff from sheet soil removal plots therefore was carrying about twice the sediment yield per unit of runoff as was found from plots that had microchannels (Table 3).

\section{Channels}

It was visually observed that sinuosity of the microchannels did not change following rainfall simulations and no significant differences were found for the average microchannel sinuosity among the two range conditions, the three soil surface configuration treatments, or the two soil removal levels. It was anticipated that microchannel sinuosity might have an effect on several runoff parameters. However, statistical analysis showed that channel sinuosity had no effect on time to runoff $(P=0.48)$ or total runoff $(P=0.99)$. A regression analysis indicated that little correlation existed between the sinuosity of the channel and sediment yield per unit runoff $(P=$ $0.52)$.

Another hypothesis tested was that microchannels not would change in depth and width during rainfall simulations. Cross-sectional measurements of the microchannels showed that the channels had widened slightly and the banks had become steeper following rainfall simulations. The average change in channel area was significantly greater for microchannels in good range condition plots than for microchannels in fair condition plots (Table 4). We therefore rejected our hypothesis that microchannels would not increase in depth or width during an intense rainfall event. These results are consistent with the sediment yield per unit runoff data that showed significantly more sediment yield per unit runoff from good range condition plots (Table 3). The increase in channel area would account for the greater loss of sediment. There was also a significant increase in single microchannel size, compared with multiple microchannel size (Table 4). This, however, did not result in an increase in sediment yield. One explanation is that the erosive forces of runoff were concentrated into one channel, rather than into multiple channels.

\section{MANAGEMENT IMPLICATIONS}

While this study was not all-inclusive, it provides insights into how microchannels may affect runoff and sediment yield. It appears that if microchannels do develop in sod-grass vegetation, this may result in more runoff, but the runoff will not contain as much sediment as might occur in bunchgrass rangelands with more bare ground in interspaces between plants. Surface roughness was a significant variable in two runoff models, but the use of standard deviation as a measure of surface roughness must be questioned because it could not detect the presence of created microchannels. The study also indicated that if shortgrass rangeland condition declined from good to fair condition, with this change to a lower range condition where buffalo grass dominated, we might expect to find greater runoff volume, but less surface soil lost to erosion. Although buffalo grass sod protects the soil surface from raindrop impact, much of the water does not infiltrate and runs off the surface. If the objective is to reduce sediment movement, then management should favor buffalo grass-dominated prairie. But if greater infiltration is more important than sediment movement, then shortgrass should be managed to favor blue grama and western wheatgrass. There may exist, however, some optimum combination of buffalo grass, blue grama, and western wheatgrass that would allow for a high infiltration rate, while still protecting the soil surface and reducing sediment export. Additional research is needed to 1) determine the amount of sediment loss during microchannel formation; 2) quantify the spatial location of vegetation and bare ground for more accurate predictions of runoff and sediment yield; 3) determine the effects of morphological characteristics of vegetation on soil erosion rates; and 4) collect and analyze various types of hydraulic roughness in microchannels to understand how they affect runoff and sediment yield.

\section{ACKNOWLEDGMENTS}

Authors wish to thank Dennis Muller, Tom Bates, Tara Sullivan, Jen Abbot, Christian Pitcher, Allie Grow, Brigid Baldwin, Andrew Trlica, Michelle Burri, and Sarah Flath for making this research project possible.

\section{LITERATURE CITED}

Abrahams, A. D., and A. J. Parsons. 1990. Determining the mean flow depth of overland flow in field studies of flow hydraulics. Water Resources Research 26:501-503.

Abrahams, A. D., A. J. Parsons, and S. H. Luk. 1986. Resistance to overland flow on desert hillslopes. Journal of Hydrology 88:343-363.

Abrahams, A. D., A. J. Parsons, and J. Wainwright. 1995. Controls and determination of resistance to overland flow on semiarid hillsopes, Walnut Gulch. Journal of Soil and Water Conservation 50:457-460.

Blackburn, W. H., R. W Knight, M. K. Wood, and L. B. Merrill. 1980. Watershed parameters as influenced by grazing. In: Proceedings, Symposium of 
Watershed Management. Boise, ID, USA: American Society of Civil Engineers. p. 552-572.

Blackburn, W. H., F. B. Pierson, C. L. Hanson, T. L. Thurow, and A. L. Hanson. 1992. The spatial and temporal influence of vegetation on surface soil factors in semiarid rangelands. Transactions of the American Society of Agriculture Engineers 35:479-486.

Blackburn, W. H., T. L. ThuRow, and C. A. Taylor. 1986. Soil erosion on rangelands. In: Proceedings, Use of Cover, Soils and Weather Data in Rangelands Monitoring Symposium. Denver, CO, USA: Society for Range Management. p. 31-39.

Bonham, C. D. 1989. Measurements for terrestrial vegetation. New York, NY, USA: John Wiley and Sons, Inc. $338 \mathrm{p}$.

Branson, F. A., G. F. Gifford, K. G. Renard, and R. F. Hadley. 1981. Rangeland hydrology. Society for Range Management, Range Science Series 1. Dubuque, IA, USA: Kendall/Hunt Publishing Co. 340 p.

Brooks, K. N., P. F. Ffolliott, H. M. Gregersen, and L. F. DeBano. 1997. Hydrology and the management of watersheds. 2nd ed. Ames, IA, USA: Iowa State University Press.

Dee, R. F., T. W. Box, and E. Robertson. 1966. Influence of grass vegetation on water intake of Pullman silty clay loam. Journal of Range Management 19:7-79.

Dunne, T., W. Zhang, and B. F. Aubry. 1991. Effects of rainfall, vegetation, and microtopgraphy on infiltration and runoff. Water Resources Research 27:2271-2285.

Fernald, A. G. 1997. Microtopographic flow paths and riparian surface hydrology [dissertation]. Fort Collins, C0, USA: Colorado State University. 134 p.

Fiedler, F. R., G. W. Frasier, J. A. Ramirez, and L. R. Ahuja. 2002. Hydrologic response of grasslands: effect of grazing, interactive infiltration, and scale. Journal of Hydrologic Engineering 7:1-9.

Flenniken, M., R. R. McEldowney, W. C. Leininger, G. W. Frasier, and M. J. Trlica. 2001. Hydrologic responses of a montane riparian ecosystem following cattle use. Journal of Range Management 54:567-574.

Frasier, G. W., And K. A. Holland. 2004. Rangeland hydrology research: lessons we have learned in 40 years. In: G. G. Ice and J. D. Stednick [EDS.]. A century of forest and wildland watershed lessons, grandmasters of watershed management. Bethesda, MD, USA: Society of American Foresters. p. 263-275.

Frasier, G. W., M. A. Weltz, and L. Weltz. 1998. Technical note: rainfall simulator runoff hydrograph analysis. Journal of Range Management 51:531-535.

Giordanengo, J. H., G. W. Frasier, and M. J. Trlica. 2003. Hydrologic and sediment responses to vegetation and soil disturbances. Journal of Range Management 56:152-158.

GutierRez-Castillo, J. 1994. Infiltration, sediment, and erosion under grass and shrub cover in the southern high plains [dissertation]. Lubbock, TX, USA: Texas Tech University.

GuY, B., W. Dickinson, ANd R. Pudra. 1992. Evaluation of fluvial sediment transport equations for overland flow. Transactions of the American Society Agricultural Engineers 35:545-555.

Intergovermental Panel on Climate Change. 2007. Climate change 2007: the physical science basis. In: S. Solomon, D. Qin, M. Manning, Z. Chen, M. Marquis, K. B. Averyt, M. Tignor, and H. L. Miller [EDS.]. 2007. Contribution of working group I to the fourth assessment report. Cambridge, UK: Cambridge University Press.

KoLER, S. 2004. Microchannels affect runoff and sediment yield from a shortgrass prairie [thesis]. Fort Collins, CO, USA: Colorado State University. 88 p.

LINSE, S. D. 1992. The influence of ground cover on upland range erosion [thesis]. Laramie, WY, USA: University of Wyoming. 98 p.
Linse, S. J., D. E. Mergen, J. L. Smith, and M. J. Trlica. 2001. Upland erosion under a simulated most damaging storm. Journal of Range Management 54:356-361.

Long Term Ecological Research. 2001. Available at: http://sgsiter.coloradostate.edu. Accessed 24 July 2008.

Mazarak, A. P., and E. C. Conrad. 1959. Rates of water entry in three great soil groups after seven yeas in grasses and small grains. Agronomy Journal 51:264-267.

MeEuWIG, R. 0. 1969. Infiltration and soil erosion as influenced by vegetation and soil in northern Utah. Journal of Range Management 23:185-189.

Mergen, D. E., M. J. Trlica, J. L. Smith, and W. H. Blackburn. 2001. Stratification of variability in runoff and sediment yield based on vegetation characteristics. Journal of the American Water Resources Association 37:617-628.

Natural Resources Conservation Service. 1997. National range and pasture handbook. Washington, DC, USA: US Government Printing Office. p. 23-26.

Owens, L., W. Edwards, and R. KeuRen. 1991. Baseflow and stormflow transport of nutrients from mixed agricultural watershed. Journal of Environmental Quality 20:407-414.

Pimentel, D. C., H. P. Resosudarmo, K. Sinclair, D. Kurz, M. McNair, S. Crist, L. Shpritz, L. Fitton, R. Saffouri, and R. Blair. 1995. Environmental and economic cost of soil erosion and conservation benefits. Science 267:1117-1123

Raff, D., J. L. Smith, and M. J. Trlica. 2003. Statistical description of channel networks and their shapes on non-vegetated hillslopes in Kemmerer, Wyoming. Hydrological Processes 17:1887-1897.

Reid, K. D., B. P. Wilcox, D. D. Breshears, and L. MacDonald. 1999. Runoff and erosion in a pinyon-juniper woodland. Soil Science Society of America Journal 63:1869-1879.

SAS InstituTE. 1988. SAS/STAT user's guide. Release 6.03. Cary, NC, USA: SAS Institute.

Simanton, J. R., M. A. Weltz, and H. D. Larson. 1991. Rangeland experiments to parameterize the water erosion prediction project model: vegetation canopy cover effects. Journal of Range Management 44:276-282.

Thomas, G. W., AND V. A. Young. 1954. Relation of soils, rainfall and grazing management to vegetation, Western Edwards Plateau of Texas. College Station, TX, USA: Texas Agriculture Experiment Station Bulletin 786.

Thorne, M. S., M. J. Trlica, W. C. Leininger, R. D. Child, and D. A. Klein. 2005. Soil $\mathrm{CO}_{2}$ efflux responses to soil loss on 2 rangeland ecosystems. Rangeland Ecology and Management 58:27-34.

Thurow, T. L., W. H. Blackburn, and C. A. Taylor, JR. 1986. Hydrologic characteristics of vegetation types as affected by livestock grazing systems, Edwards Plateau, Texas. Journal of Range Management 39:505-509.

Tromble, J. M., K. G. Renard, and A. P. Thatcher. 1974. Infiltration for three rangeland soil-vegetation complexes. Journal of Range Management 27:318-321.

[USDA] US Department of Agriculture. 1982. Soil survey of Weld County, Colo. northern part. Washington, DC, USA: US Government Printing Office.

VanAmburg, L. K., R. D. Child, M. J. Trlica, and G. W. Frasier. 1999. Soil and vegetation characteristics on good and fair shortgrass steppe. Townsville, Australia: Proceedings of the VI International Rangeland Congress 2. p. 752-753.

Wilcox, B. P., AND M. K. Wood. 1989. Factors influencing interrill erosion from semiarid slopes in New Mexico. Journal of Range Management 42:66-70.

Wischmeier, W. H., And D. D. Smith. 1978. Predicting rainfall erosion losses-a guide to conservation planning. Washingtion, DC, USA: US Government Printing Office, Agriculture Handbook 537. 